Apailable online on 15.04.2020 at http://jddtonline.info
Open Access to Pharmaceutical and Medical Research
unrestricted non-commercial use, provided the original work is properly cited

Open 1 Access

Research Article

\title{
Evaluation of Antidiabetic and Antihyperlipidemic Effect of Ethanolic Leaves Extract of Centratherum anthelminticum (L) Kuntze against STZ Induced Diabetic Rats
}

\author{
Nidhi Goutam*, Reni Kapoor \\ Pharmacy Department, L.T.R. Institute of Technology, Baghpat Road, Meerut (U.P)
}

\begin{abstract}
Objective: To evaluate the Antidiabetic \& Antihyperlipidemic effect of Centratherum Anthelminticum (L) Kuntze extract against STZ induced diabetic rats.

Methods: The present study examined the influence of Centratherum Anthelminticum extract (CASE), on blood glucose level and antioxidant enzymes level in STZ induced diabetic rats. The possible effects of chronic administration of the extract on the fasting serum glucose, insulin, and total cholesterol and triglycerides levels in STZ-induced diabetic rats were also evaluated.

Results: The extracts showed a marked Antidiabetic \& Antihyperlipidemic effect. Centratherum anthelminticum ethanolic seeds extract is capable of exhibiting glycemic control through its inhibitory effect on glycogenolytic enzyme glycogen phosphorylase, glucone ogenic enzymes such as glucose-6-phosphatase and fructose-1, 6-bis phosphatase and stimulatory effect on hexokinase, which is the key enzyme in the glycolytic pathway.

Antihyperlipidemic activity of Centratherum anthelminticum ethanolic seeds extract proved by restoration of altered lipid profile

Conclusions: The results of the study indicate that the extract of Centratherum anthelminticum possesses strong antidiabetic \& antihyperlipidemic activity. This study also describes therapeutic effect of Centratherum anthelminticum in diabetes which will give a new direction for the future scientific research.
\end{abstract}

Keywords: Diabetes, Centratherum anthelminticum, Pharmacological, Antidiabetic, Antihyperlipidemic

Article Info: Received 19 Dec 2019; Review Completed 25 Feb 2020; $\quad$ Accepted 05 April 2020; Available online 15 April 2020

Cite this article as:

Goutam N, Kapoor R, Evaluation of Antidiabetic and Antihyperlipidemic Effect of Ethanolic Leaves Extract of Centratherum anthelminticum (L) Kuntze against STZ Induced Diabetic Rats, Journal of Drug Delivery and Therapeutics. 2020; 10(2-s):140-148 http://dx.doi.org/10.22270/jddt.v10i2-s.4014

*Address for Correspondence:

Ms. Nidhi Goutam, L.T.R. Institute of Technology, Baghpat Road, Meerut, Uttar Pradesh 250002

\section{INTRODUCTION}

Diabetes mellitus is a metabolic disorder with high blood sugar levels over a prolonged period of time. Symptoms of high blood sugar may be polyuria, polydipsia and polyphagia. Diabetes mellitus is a chronic metabolic disorder characterized by a high blood glucose concentration hyperglycemia (fasting plasma glucose $>126 \mathrm{mg} / \mathrm{dL}$, or plasma glucose $>200 \mathrm{mg} / \mathrm{dL} 2 \mathrm{hrs}$ after a meal) - caused by insulin deficiency, often combined with insulin resistance. In diabetic patients, oxidative stress also has been found to be mainly due to increased production of oxygen free radicals and sharp reduction of anti-oxidant defense 1 . Hypoinsulinemia associated with diabetes increased the activity of enzyme, fatty acyl Coenzyme A oxidase which initiates the $\beta$-oxidation of the fatty acids, resulting in lipid peroxidation. Increased lipid peroxidation impairs membrane function by decreased membrane fluidity and changing the activity of the membrane-bound enzyme and receptors 2 . Its products (lipid radices and lipid peroxides) are harmful to the cell in the body and associated with atherosclerosis and brain damage. Diabetes Mellitus is associated with abnormalities in carbohydrates and lipid metabolism that results in excessive production of reactive oxygen species [ROS] and oxidative stress ${ }^{3}$.

Therefore the present study is undertaken to evaluate antidiabetic and anti-oxidant activity of $C$. anthelminticum in STZ induced diabetic rats.

The ethnobotanical information reports about 800 plants that may possess antidiabetic potential. Folk medicine for diabetes from Rayalaseema reports 26 plants with antidiabetic activity. One such plant is $C$. anthelminticum synonyms; Vernonia anthelmintica, Conyza anthelmintica belongs to the family Asteraceae. In Hindi it is known as Kalizeeri 4. 


\section{Description of Plant}

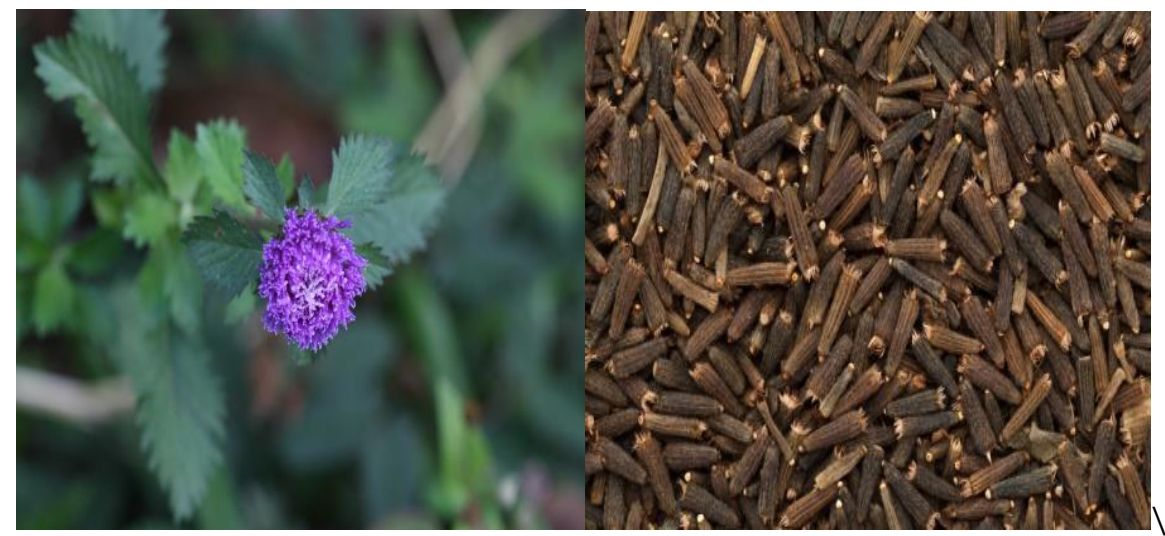

Centratherum Anthelminticum (L) Kuntze plant and closed Seeds

Ethno medicinal \& traditional uses of different parts of Centratherum anthelminticum

The Indications of Leaves of $C$. anthelmintic are rheumatism, chronic persistent fevers, phlegmatic cough, and dropsy. The indications of Seed of $C$. anthelmintic are kidney troubles, pustules, skin irritation, hiccough, eye itching, cold phlegmatic inflammation, chronic persistent fevers, dysuria, rheumatism, leucoderma, psoriasis, colic, vitiligo, sores, asthma, and pimples.

Roots of $C$. anthelmintic are used in rheumatic swellings. Seed (powder) of $C$. anthelminticum is used in pimples, thread worms, irritative skin \& round worms 5 .

Herb Paste of $C$. anthelminticum is used in skin eruptions, rheumatism. The Indications of infusion (seed) of $C$ anthelmintic are phlegmatic cough, dropsy, rheumatic affections, and chronic persistent fevers 6 .

\section{Significance of the Study}

C. anthelminticum is an important drug of indigenous system of medicine and has been known for a number of medicinal properties in Ayurveda. C. anthelminticum is used as folkmedicine for diabetes in Rayalaseema of Andhra Pradesh of India but still its pharmacological potential for anti-diabetic activity has not been fully explored 7 . This study will try to provide scientific basis for the further development of antidiabetic activity of herbal drugs.

\section{MATERIAL AND METHOD}

- Collection \& identification of plant material C. anthelminticum (L) kuntze.

- Preparation of ethanolic extract of C. anthelminticum.

The powdered seeds (200 g) are extracted with $1 \mathrm{l}$ of $95 \%$ ethanol in a soxhlet extractor for $24 \mathrm{~h}$. The solvent is recovered by distillation in vacuo which yielded a dark brown oily semisolid residue. The oil is separated from the extract on standing and the resultant extract is used for further studies ${ }^{8}$.

\section{Chemicals and reagents}

STZ, RIA kit serum insulin level, GOD-POD kit serum glucose level, Glibenclamide, Ammonium thiocyanate, 1,1-diphenyl2- picryl-hydrazyl (DPPHd), 3-(2-Pyridyl)-5,6-bis (4- phenylsulfonic acid)-1,2,4-triazine (Ferrozine), Griess reagent, Colchicine, Ellman's Reagent (DTNB), acetylthiocholine iodide, bovine serum albumin, thiobarbituric acid and 1, 1, 3, 3-tetraethoxypropane (MDA) were purchased from Sigma chemical . Butylated hydroxytoluene (BHT), hydroxylamine, ferrous chloride, Ascorbic acid (Vitamin C), nitro blue tetrazolium, EDTA, $\beta$ - carotene, Tween-80, trichloracetic acid (TCA), hematoxylin and eosin were purchased from Himedia Co. Chloral hydrate, isotonic saline, sodium carbonate, , $4 \%$ paraformaldehyde, paraffin, were purchased from Central Drug House Laboratory (CDH). All others unlabelled chemicals and reagents were analytical grade ${ }^{9}$.

\section{Plant materials}

Fresh leaves and flowers of $C$. anthelminticum seed were collected from the khari baoli; chandni chowk Delhi .The plant was authenticated by Dr. Anjula Pandey, Principal Scientist National Herbarium of Cultivated Plants (NHCP) Division of Plants Exploration and Germplasm Collection, National Bureau of Plant Genetic Resources, New Delhi. The voucher specimen (NHCP/NBPGR/2018/39) of the plant material has been deposited in the Department.

\section{Preparation of ethanolic extract}

C. anthelminticum seed were dried under shade coarsely powdered and passed through 40 mesh sieves. Successive solvent extraction scheme was followed for the preparation of different extracts ${ }^{10}$. Coarsely powdered $C$. anthelminticum seed were defatted with petroleum ether using Soxhlet apparatus. The dried marc was further extracted with ethanol using Soxhlet apparatus. Solvent was removed under reduced pressure using rotary evaporator to yield dried ethanolic extract 11.

\section{Induction of diabetes \& Experimental design 12}

Assessment of antihyperglycemic effect of ethanolic extract of C. anthelminticum seeds in normal and STZ induced diabetic rats:

Body weights of the animals were recorded and they were divided into 7 groups of 6 animals each as follows

Group I: Normal rats were administered with CMC

Group II: Diabetic control - Rats were induced with Streptozotocin in normal saline at a dose of $60 \mathrm{mg} / \mathrm{kg}$ body weight IP.

Group III: Groups of diabetic rats treated with ethanolic extract of $C . A(100 \mathrm{mg} / \mathrm{kgbw})$ orally for 60 days

Group IV: Groups of diabetic rats treated with ethanolic extract of $C . A(200 \mathrm{mg} / \mathrm{kgbw})$ orally for 60 days

Group V : Groups of diabetic rats treated with ethanolic extract of $C . A(300 \mathrm{mg} / \mathrm{kgbw})$ orally for 60 days 
Group VI: Normal rats were administered orally the ethanolic extract of Centratherum anthelminticum (300mg/kgbw) for 60 days.

Group VII: Groups of diabetic rats treated with Glibenclamide (5 mg/kgbw/oral) for 60 days

\section{Animal care and selection}

Adult male Swiss albino mice were obtained from the suitable source. They will be housed in polypropylene cages in groups of six mice per cage and kept in a room maintained at $25 \pm 2{ }^{\circ} \mathrm{C}$ with a 12 -h light/dark cycle. They will be allowed to acclimatize for 1 week before the experiments and will be given free access to standard laboratory feed and water ad libitum. Protocol is approved by Institutional animal ethics committee.

\section{Acute toxicity study}

The acute toxicity study will be performed according to OECD guideline 423. The adult Albino Swiss mice 20-25 g will be randomly divided into five groups containing three animals in each group. The animals will be fasted overnight, and the $C$. anthelminticum seeds extracts will be administered orally of various dose levels (mg/kg, BW) suspended in $0.5 \%$ Carboxymethyl cellulose. Fifth group will be maintained as control and administered the vehicle only. The animals will be observed continuously for $2 \mathrm{~h}$, then occasionally for a further $24 \mathrm{~h}$, and finally any mortality. The behaviour of the animals and any other toxic symptoms will be observed for $72 \mathrm{~h}$, and they were kept under observation for one week ${ }^{13}$.

\section{Evaluation of Biochemical Parameters}

Estimation of serum glucose level (GOD-POD method), serum insulin level (RIA method), serum cholesterol (enzymatic method), HDL cholesterol (enzymatic method), serum triglyceride (enzymatic method), serum urea (Berthelot method) and creatinine (alkaline picrate method) has to done. VLDL-cholesterol and LDL- cholesterol are calculated as per Friedewald' equation ${ }^{14}$.

\section{VLDL-cholesterol $=$ total serum triglycerides $/ 5$}

LDL-cholesterol $=$ Total serum cholesterol- total serum triglycerides/5-HDL-C

Estimation of total cholesterol \& triglyceride: $1.0 \mathrm{ml}$ of isopropanol was mixed with $0.1 \mathrm{ml}$ of sample and $0.1,0.2$, $0.3,0.4$ and $0.5 \mathrm{ml}$ of standard solution. To this $0.4 \mathrm{~g}$ of alumina was added and mixed well for $15 \mathrm{~min}$. The content was centrifuged at $3000 \mathrm{rpm}$ for 10 minutes and $0.5 \mathrm{ml}$ of the supernatant was transferred to reaction tubes and heated at $65{ }^{\circ} \mathrm{C}$ for $15 \mathrm{~min}$. Then

$0.6 \mathrm{ml}$ of the saponification reagent was added and cooled. Then $1.0 \mathrm{ml}$ of sodium metaperiodate and $0.5 \mathrm{ml}$ of acetyl acetone reagent were added and heated at $65 \stackrel{\circ}{\circ} \mathrm{C}$ for 30 minutes. The contents were cooled and the colour developed was read at $430 \mathrm{~nm}$.

From the standard optical density values, the amount of triglyceride in the sample was calculated and expressed as $\mathrm{mg} / \mathrm{dl}{ }^{15}$.

\section{Estimation of phospholipids}

$0.1 \mathrm{ml}$ of sample (tissue lipid) was digested with $0.2 \mathrm{ml}$ of perchloric acid over a sand bath. Digestion was continued till it was colorless. The liberated phosphorus was estimated. $4.3 \mathrm{ml}$ of deionised water was added to the digested sample followed by $0.5 \mathrm{ml}$ of ammonium molybdate. After $10 \mathrm{~min}$
$0.2 \mathrm{ml}$ of ANSA was added. Tubes were well shaken and kept aside for 20 mins. Blue colour read at $620 \mathrm{~nm}$. The total phospholipids were estimated by multiplying the value of $\mathrm{Pi}$ by 25 and expressed as $\mathrm{mg} / \mathrm{g}$ wet tissue 16 .

\section{Estimation of HDL cholesterol}

To $1.0 \mathrm{ml}$ of lipid extract, $0.18 \mathrm{ml}$ of heparin manganese chloride reagent was added and mixed. This was allowed to stand in an ice bath for 30 minutes and then centrifuged in a refrigerated centrifuge $2500 \mathrm{~g}$ for 30 minutes. The supernatant contained HDL fraction. Aliquots of the HDL supernatant were estimated for cholesterol, phospholipids 17.

\section{Estimation of VLDL}

To $1 \mathrm{ml}$ of lipid extract was added to $0.15 \mathrm{ml}$ of SDS solution. The contents were mixed well and incubated for 2 hours. The contents were centrifuged in a refrigerated centrifuge at $10,000 \mathrm{~g}$ for 30 minutes. VLDL aggregated as a pellicle at the top. The supernatant was a mixture containing HDL and LDL fractions. The fractions of lipoproteins were assayed after heparin manganese chloride and SDS precipitation. The values are expressed in $\mathrm{mg} / \mathrm{dl}$ plasma. After precipitation the cholesterol levels in supernatant was measured to get HDL cholesterol. SDS precipitated VLDL and the cholesterol content in the supernatant was measured for HDL cholesterol, LDL cholesterol and VLDL cholesterol 18.

\section{Evaluation of antioxidant Parameters}

Animal are scarified at the end of 28 days treatment. The liver of animal is dissected out, rinsed with ice cold distilled water followed by sucrose solution $(0.25 \mathrm{M})$. One gm of liver tissue is homogenized in $10 \mathrm{ml}$ ice cold Tris hydrochloride buffer. The prepared homogenates are centrifuged and used for the determination of antioxidant parameters like Malondialdehyde (MDA), Superoxide dismutase (SOD), catalase, Reduced Glutathione (GSH) levels and total protein estimation. Liver and kidney are isolated from one animal of each group and used for histopathology 19.

Measurement of MDA i.e. lipid peroxidation, was measured spectrophotometrically by the method of using $1,1,3,3$ tetraethoxypropane as standard. MDA is expressed as nanomoles per mg protein. GSH was determined by its reaction with 5, 5'-dithiobis (2-nitrobenzoic acid) (Ellman1959) to yield a yellow chromophore which was measured spectrophotometrically. GSH is expressed as $\mu \mathrm{g} /$ mg protein 20 . Nitrite is a stable end product of nitric oxide metabolism (as RNI) was measured in brain homogenate by Griess method. Briefly, the following procedure was adapted. The sample and reagents were well mixed and incubated for $10 \mathrm{~min}$ at room temperature in dark. Then absorbance was taken at $540 \mathrm{~nm}$. The concentration of nitrite in supernatant was determined from sodium nitrite standard curve 21 .

\section{Histopathological studies}

For histopathological study, the tissues were fixed in Bouin's fluid. The classical paraffin sectioning, and haematoxylin eosin staining techniques were used for histopathological studies. The various steps involved in the preparation of tissues for histopathological studies were: carried out 22 .

\section{Statistical analysis}

The results are expressed as mean \pm S.E.M. Statistical analysis of passive avoidance, Morris water maze and biochemical values were performed by comparison Duncan's multiple range test (DMRT). 


\section{RESULT AND DISCUSSION:}

Anti-diabetic activity of ethanolic leaves extract of Centratherum anthelminticum

Effect of ethanolic leaves extract on Body weight, of experimental animals

Body weights of the animals were recorded and they were divided into 7 groups of 6 animals each as follows

\section{Body weight}

The effect of administration of different doses $(100,200$ and $300 \mathrm{mg} / \mathrm{kg}$ ) of ethanolic leaves extract of Centratherum anthelminticum and Glibenclamide on body weight of rats during the experimental period is summarized on Table 4.15 \& Fig 4.10. Diabetes- induced animals showed significant decrease $(\mathrm{p}<0.05)$ in body weight day by day when compared with control animals. The ethanolic extract of Centratherum anthelminticum treated animals were found to be have significant increase $(\mathrm{p}<0.05)$ in body weight when compared with diabetes-induced animals. The results showed significant dose dependent increase in the body weight of the diabetic rats treated with the leaves extracts and the standard drug. The increase in ethanol extract treated group was similar to the normal group. There is no significant changes were observed in Centratherum anthelminticum alone (without induction of diabetes) treated rats 23 .

Table 1: Effect of ethanolic leaves extract on Body Weight of experimental animals

\begin{tabular}{|c|c|c|c|c|c|}
\hline \multirow[b]{2}{*}{ Groups } & \multicolumn{5}{|c|}{ Body Weight(g) } \\
\hline & $0^{\text {th }}$ day & $15^{\text {th }}$ day & $30^{\text {th }}$ day & $45^{\text {th }}$ day & $60^{\text {th }}$ day \\
\hline I & $180.00 \pm 3.33^{\mathrm{a}}$ & $201.25 \pm 3.49^{\mathrm{a}}$ & $215.00 \pm 1.67^{\mathrm{a}}$ & $237.50 \pm 4.86^{\mathrm{a}}$ & $248.75 \pm 3.49^{\mathrm{a}}$ \\
\hline II & $187.50 \pm 3.91^{a}$ & $151.25 \pm 2.57^{\mathrm{b}}$ & $145.00 \pm 1.94^{\mathrm{b}}$ & $132.50 \pm 2.64^{\mathrm{b}}$ & $126.50 \pm 2.46^{\mathrm{b}}$ \\
\hline III & $180.00 \pm 15.09^{\mathrm{a}}$ & $196.25 \pm 4.53^{\mathrm{a}}$ & $215.00 \pm 12.69^{a}$ & $240.50 \pm 17.12^{a}$ & $231.25 \pm 12.73^{a}$ \\
\hline IV & $182.50 \pm 13.49^{\mathrm{a}}$ & $205.00 \pm 15.46^{\mathrm{a}}$ & $210.00 \pm 26.77^{\mathrm{a}}$ & $238.00 \pm 30.55^{a}$ & $242.50 \pm 25.47^{a}$ \\
\hline $\mathbf{V}$ & $185.00 \pm 12.69^{\mathrm{a}}$ & $210.00 \pm 10.74^{\mathrm{a}}$ & $220.50 \pm 20.10^{\mathrm{a}}$ & $235.00 \pm 20.28^{\mathrm{a}}$ & $245.50 \pm 28.94^{a}$ \\
\hline VI & $186.00 \pm 11.06^{\mathrm{a}}$ & $202.00 \pm 11.73^{\mathrm{a}}$ & $160.00 \pm 18.56^{a}$ & $230.50 \pm 16.46^{\mathrm{a}}$ & $238.00 \pm 21.21^{a}$ \\
\hline VII & $185.00 \pm 2.36^{\mathrm{a}}$ & $200.00 \pm 13.49^{\mathrm{a}}$ & $204.50 \pm 20.38^{a}$ & $217.50 \pm 21.95^{a}$ & $240.00 \pm 21.86^{a}$ \\
\hline
\end{tabular}

Values are expressed as Mean \pm SD for six rats. Mean values within a graph followed by different letters are significantly different from each other at $\mathrm{P}<0.05$ level comparison by Duncan's multiple range test (DMRT)

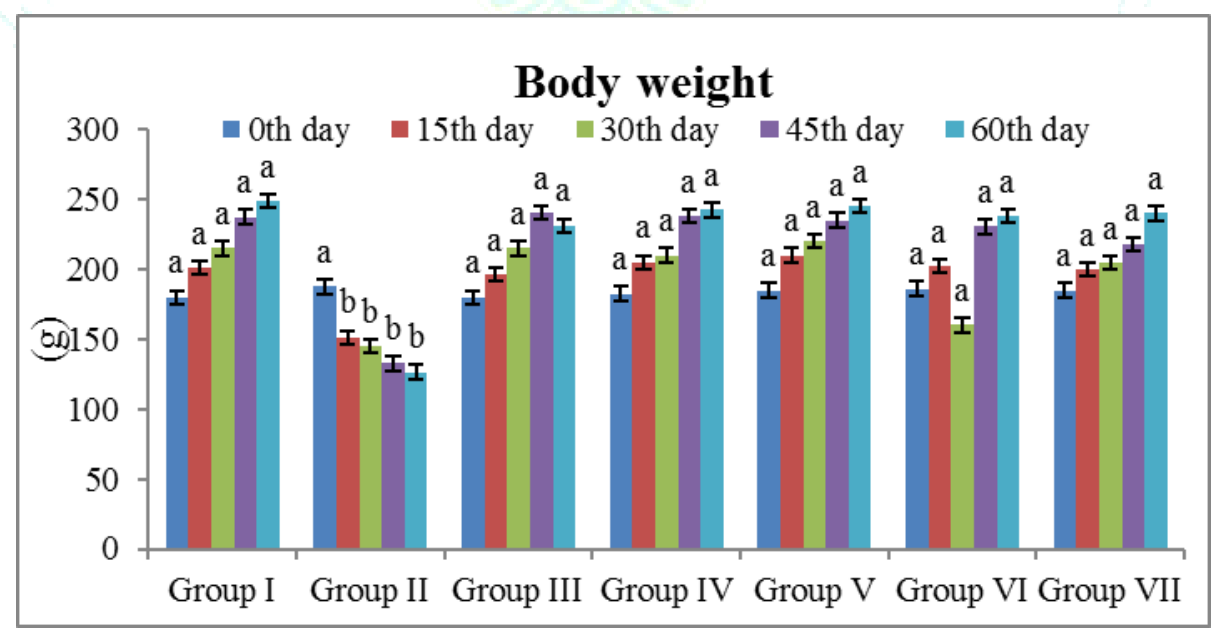

Fig 1: Effect of ethanolic seeds extract on Body Weight, of experimental animals

Table 2: Effect of ethanolic seeds extract on Glucose (mg/dl) of experimental animals

\begin{tabular}{|c|l|l|l|l|l|}
\hline Groups & \multicolumn{5}{|c|}{ Glucose (mg/dl) } \\
\cline { 2 - 6 } & $4^{\text {th }}$ day & $\mathbf{1 5}^{\text {th }}$ day & $\mathbf{3 0}^{\text {th }}$ day & $\mathbf{4 5}^{\text {th }}$ day & $\mathbf{6 0}^{\text {th }}$ day $^{\text {I }}$ \\
\hline II & $106.40 \pm 1.62^{\mathrm{a}}$ & $103.60 \pm 0.68^{\mathrm{a}}$ & $103.75 \pm 0.66^{\mathrm{a}}$ & $103.75 \pm 0.66^{\mathrm{a}}$ & $104.00 \pm 0.66^{\mathrm{a}}$ \\
\hline III & $178.00 \pm 4.43^{\mathrm{b}}$ & $222.60 \pm 0.47^{\mathrm{b}}$ & $225.60 \pm 0.47^{\mathrm{b}}$ & $228.60 \pm 0.47^{\mathrm{b}}$ & $231.60 \pm 0.47^{\mathrm{b}}$ \\
\hline IV & $151.00 \pm 5.85^{\mathrm{c}}$ & $212.45 \pm 0.34^{\mathrm{c}}$ & $207.45 \pm 0.34^{\mathrm{c}}$ & $202.45 \pm 0.34^{\mathrm{c}}$ & $197.45 \pm 0.34^{\mathrm{c}}$ \\
\hline V & $142.00 \pm 2.33^{\mathrm{c}}$ & $207.95 \pm 0.34^{\mathrm{c}}$ & $199.95 \pm 0.34^{\mathrm{c}}$ & $191.95 \pm 0.34^{\mathrm{c}}$ & $183.95 \pm 0.34^{\mathrm{c}}$ \\
\hline VI & $114.00 \pm 2.71^{\mathrm{a}}$ & $103.95 \pm 0.34^{\mathrm{a}}$ & $102.70 \pm 0.34^{\mathrm{a}}$ & $117.70 \pm 0.34^{\mathrm{a}}$ & $118.70 \pm 0.34^{\mathrm{a}}$ \\
\hline VII & $107.60 \pm 1.57^{\mathrm{a}}$ & $103.45 \pm 0.68^{\mathrm{a}}$ & $103.60 \pm 0.66^{\mathrm{a}}$ & $104.23 \pm 0.66^{\mathrm{a}}$ & $104.35 \pm 0.66^{\mathrm{a}}$ \\
\hline
\end{tabular}

Values are expressed as Mean \pm SD for six rats. Mean values within a graph followed by different letters are significantly different from each other at $\mathrm{P}<0.05$ level comparison by Duncan's multiple range test (DMRT) 
Effect of Centratherum anthelminticum ethanolic seeds extract on HDL, LDL, VLDL, FFA, PL and TC of experimental animals.

Total cholesterol (TC), Triglycerides (G), Phospholipids (PL), free fatty acid (FFA), Low Density Lipoprotein (LDL), High Density Lipoprotein (HDL) and Very Low Density Lipoprotein (VLDL) content was shown in Table 4.18 and Fig 4.14. Streptozotocin induced diabetic rats showed increased LDL $(245.57 \mathrm{mg} / \mathrm{dl}), \mathrm{TG}(353.60 \mathrm{mg} / \mathrm{dl})$, VLDL $(78.93 \mathrm{mg} / \mathrm{dl})$, FFA $(2.77 \mathrm{mg} / \mathrm{dl})$, PL $(1.96 \mathrm{mg} / \mathrm{dl}), \mathrm{TC}(392.00 \mathrm{mg} / \mathrm{dl})$ while decreased HDL (26.60mg/DL) content was observed ${ }^{24}$.Administration of different doses $(100,200$ and $300 \mathrm{mgkg})$ of ethanolic leaf extract of Centratherum anthelminticum decreased content in LDL, TC, VLDL, FFA, PL, TC and increased HDL content was observed dose dependent manner. Among the various doses, the highest dose $(300 \mathrm{mg} / \mathrm{kg})$ of leaf extract of Centratherum anthelminticum shows significantly $(\mathrm{p}>0.05)$ restored the LDL $(89.90 \mathrm{mg} / \mathrm{dl})$, TG $(80.21 \mathrm{mg} / \mathrm{dl})$, VLDL $(23.93 \mathrm{mg} / \mathrm{dl})$, FFA $(1.43 \mathrm{mg} / \mathrm{dl}), \mathrm{PL}$ $(1.41 \mathrm{mg} / \mathrm{dl})$, TC $(140.54 \mathrm{mg} / \mathrm{dl})$ and increased HDL (70.80mg/DL) content to normal rats 25 . The standard treated group also decreased LDL, VLDL, FFA, TC while increased HDL content. Centratherum anthelminticum alone $(300 \mathrm{mg} / \mathrm{kg})$ treated rats did not show any significant variation in lipid profile throughout the experimental period 26 .

Table 3: Effect of Centratherum anthelminticum ethanolic seeds extract on HDL, TG, LDL, VLDL, FFA, PL and TC of experimental animals

\begin{tabular}{|c|l|l|l|l|l|}
\hline Groups & \multicolumn{1}{|c|}{ Total Cholesterol (mg/g) } & Triglycerides (mg/g) & HDL (mg/dl) & LDL (mg/dl) & VLDL (mg/dl) \\
\hline I & $136.40 \pm 1.65^{\mathrm{a}}$ & $62.00 \pm 0.65^{\mathrm{a}}$ & $77.20 \pm 0.93^{\mathrm{a}}$ & $39.00 \pm 7.87^{\mathrm{a}}$ & $10.33 \pm 2.07^{\mathrm{a}}$ \\
\hline II & $392.00 \pm 1.12^{\mathrm{b}}$ & $353.60 \pm 1.31^{\mathrm{b}}$ & $26.60 \pm 0.98^{\mathrm{b}}$ & $245.57 \pm 49.12^{\mathrm{b}}$ & $78.93 \pm 11.79^{\mathrm{b}}$ \\
\hline III & $327.60 \pm 1.02^{\mathrm{c}}$ & $312.60 \pm 0.80^{\mathrm{c}}$ & $46.31 \pm 0.74^{\mathrm{c}}$ & $213.90 \pm 42.81^{\mathrm{c}}$ & $62.10 \pm 10.42^{\mathrm{c}}$ \\
\hline IV & $230.00 \pm 1.55^{\mathrm{d}}$ & $262.60 \pm 0.94^{\mathrm{d}}$ & $54.80 \pm 0.79^{\mathrm{d}}$ & $143.90 \pm 28.83^{\mathrm{d}}$ & $4^{\mathrm{a}}$ \\
\hline V & $140.54 \pm 0.98^{\mathrm{a}}$ & $73.60 \pm 1.10^{\mathrm{a}}$ & $70.80 \pm 0.65^{\mathrm{d}}$ & $89.90 \pm 18.02^{\mathrm{a}}$ & $23.93 \pm 4.79^{\mathrm{a}}$ \\
\hline VI & $138.60 \pm 1.77^{\mathrm{a}}$ & $80.21 \pm 0.94^{\mathrm{a}}$ & $77.80 \pm 0.79^{\mathrm{a}}$ & $68.73 \pm 13.90^{\mathrm{a}}$ & $20.27 \pm 4.06^{\mathrm{a}}$ \\
\hline VII & $144.00 \pm 1.98^{\mathrm{a}}$ & $72.80 \pm 5.10^{\mathrm{a}}$ & $81.80 \pm 0.34^{\mathrm{a}}$ & $44.70 \pm 9.15^{\mathrm{a}}$ & $7.13 \pm 1.69^{\mathrm{a}}$ \\
\hline
\end{tabular}

Values are expressed as Mean \pm SD for six rats. Mean values within a graph followed by different letters are significantly different from each other at $\mathrm{P}<0.05$ level comparison by Duncan's multiple range test (DMRT)
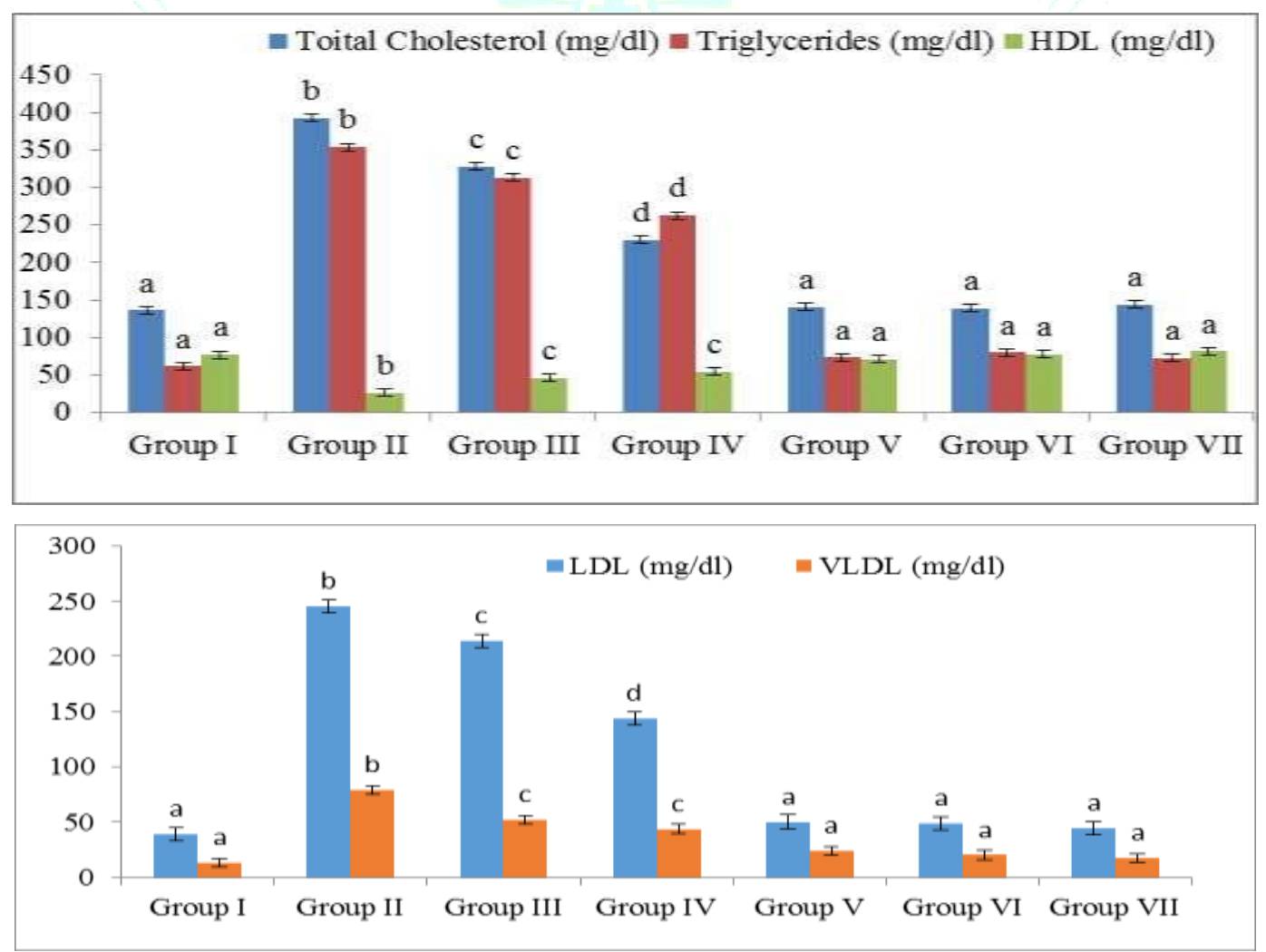

Fig 2: Effect of Centratherum anthelminticum ethanolic seeds extract on HDL, TG, LDL, VLDL, TC of experimental animals

Effect of Centratherum anthelminticum ethanolic seeds extract on liver LPO, SOD, CAT, GPx, GST, GSH of experimental animals 27

The lipid peroxidation (LPO) content, Superoxide dismutase (SOD), Catalase (CAT), Glutathione peroxidase (GPx), Glutathione S transferase (GST) activity, Reduced glutathione
(GSH), Vitamin C and E content in liver was given in Table 4.19 and Fig 4.15, 4.16 and 4.71. Streptozotocin induced diabetic rats showed increased LPO content while decreased in the activities of SOD, CAT, GPx, GST and content of GSH, Vitamin $\mathrm{C}$ and $\mathrm{E}$ was observed. Administration of different doses $(100,200$ and $300 \mathrm{mgkg})$ of ethanolic leaf extract of 
Centratherum anthelminticum decreased LPO content while increased in the activities of SOD, CAT, GPx, GST and content of GSH, Vitamin C and E was observed in dose dependent manner 24. Among the various doses, the highest dose $(300 \mathrm{mg} / \mathrm{kg}$ ) of leaf extract of Centratherum anthelminticum shows significantly $(p>0.05)$ restored the LPO content, the activities of SOD, CAT, GPx, GST and content of GSH, Vitamin $\mathrm{C}$ and $\mathrm{E}$ content to normal rats ${ }^{28}$. The standard treated group showed no significant changes were observed in antioxidant enzymes. Centratherum anthelminticum alone $(300 \mathrm{mg} / \mathrm{kg}$ ) treated rats did not show any significant variation in antioxidant status throughout the experimental period ${ }^{29}$.

Table 4: Effect of Centratherum anthelminticum ethanolic seeds extract on liver LPO, SOD, CAT, GPx \& GSH of experimental animals.

\begin{tabular}{|l|l|l|l|l|l|}
\hline Groups & $\begin{array}{l}\text { LPO (nmol } \\
\text { MDA/mg protein) }\end{array}$ & $\begin{array}{l}\text { SOD (Liver) (U/mg } \\
\text { protein) }\end{array}$ & $\begin{array}{l}\text { CAT (Liver) (U/mg } \\
\text { protein) }\end{array}$ & $\begin{array}{l}\text { GPx (U/mg } \\
\text { protein) }\end{array}$ & $\begin{array}{l}\text { GSH ( } \boldsymbol{\mu g} / \mathbf{g} \\
\text { tissue) }\end{array}$ \\
\hline Group I & $2.77 \pm 0.09^{\mathrm{a}}$ & $1600.53 \pm 4.51^{\mathrm{a}}$ & $24.0 \pm 1.5^{\mathrm{a}}$ & $997.0 \pm 151.7^{\mathrm{a}}$ & $48636.4 \pm 5.0^{\mathrm{a}}$ \\
\hline Group II & $13.91 \pm 0.08^{\mathrm{b}}$ & $825.67 \pm 2.69^{\mathrm{b}}$ & $8.8 \pm 2.3^{\mathrm{b}}$ & $434.5 \pm 251.6^{\mathrm{b}}$ & $25776.0 \pm 1.7^{\mathrm{b}}$ \\
\hline Group III & $10.05 \pm 0.06^{\mathrm{c}}$ & $1186.00 \pm 10.97^{\mathrm{d}}$ & $15.6 \pm 1.5^{\mathrm{c}}$ & $584.5 \pm 234.6^{\mathrm{d}}$ & $32124.8 \pm 2.4^{\mathrm{c}}$ \\
\hline Group IV & $7.47 \pm 0.21^{\mathrm{d}}$ & $1362.53 \pm 13.00 \mathrm{c}$ & $18.0 \pm 0.6^{\mathrm{d}}$ & $831.5 \pm 184.2^{\mathrm{c}}$ & $39684.0 \pm 2.0^{\mathrm{d}}$ \\
\hline Group V & $3.02 \pm 0.04^{\mathrm{a}}$ & $1516.80 \pm 8.12^{\mathrm{a}}$ & $22.0 \pm 1.0^{\mathrm{a}}$ & $970.0 \pm 156.4^{\mathrm{a}}$ & $46418.7 \pm 1.0^{\mathrm{a}}$ \\
\hline Group VI & $2.83 \pm 0.03^{\mathrm{a}}$ & $1599.33 \pm 6.59^{\mathrm{a}}$ & $23.0 \pm 0.7^{\mathrm{a}}$ & $995.5 \pm 151.6^{\mathrm{a}}$ & $47653.2 \pm 4.3^{\mathrm{a}}$ \\
\hline Group VII & $3.23 \pm 0.07^{\mathrm{a}}$ & $1590.53 \pm 4.51^{\mathrm{a}}$ & $24.0 \pm 1.5^{\mathrm{a}}$ & $997.0 \pm 151.7^{\mathrm{a}}$ & $48614.3 \pm 2.0^{\mathrm{a}}$ \\
\hline
\end{tabular}

Values are expressed as Mean \pm SD for six rats Mean values within a graph followed by different letters are significantly different from each other at $\mathrm{P}<0.05$ level comparison by Duncan's multiple range test (DMRT)

Effect of Centratherum anthelminticum on AST, ALT, ALP activities and Direct Bilurubin, Total Bilurubin, protein content of experimental animals 24

The AST, ALT, ALP activities and direct bilurubin, total bilurubin, protein content was represented in normal and experimental rats represented in Table 4.20 and Fig 4.18. Streptozotocin induced diabetic rats showed significantly increased in the activities of AST, ALT, ALP and content of direct bilurubin, total bilurubin while decreased protein content was observed 30 . Administration of different doses (100, 200 and $300 \mathrm{mgkg}$ ) of ethanolic leaf extract of Centratherum anthelminticum significantly restored in the activities of AST, ALT, ALP and content of direct bilurubin, total bilurubin while increased protein content was observed in dose dependent manner ${ }^{31}$. Among the various doses, the highest dose $(300 \mathrm{mg} / \mathrm{kg})$ of leaf extract of Centratherum anthelminticum shows significantly $(\mathrm{p}>0.05)$ restored the activities of AST, ALT, ALP and content of direct bilurubin, total bilurubin and protein content to normal rats ${ }^{32}$. The standard treated group showed no significant changes were observed in liver markers. Centratherum anthelminticum alone $(300 \mathrm{mg} / \mathrm{kg})$ treated rats did not show any significant variation in liver marker enzymes throughout the experimental period 33 .

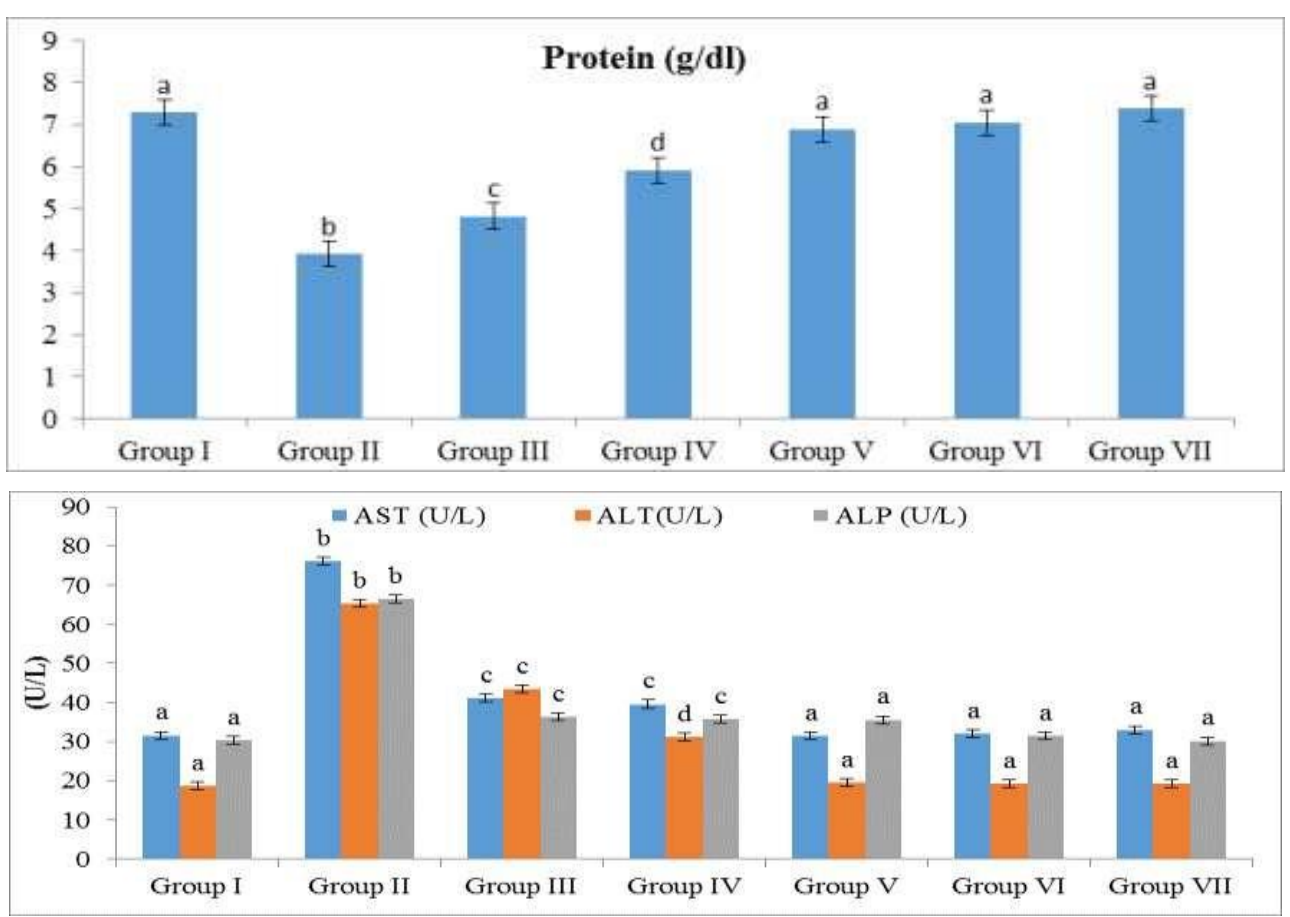

Fig 3: Effect of Centratherum anthelminticum on AST, ALT, ALP activities and Direct Bilurubin, Total Bilurubin, protein content of experimental animals 


\section{Histology of Liver ${ }^{34}$}

Photomicrographs of normal liver showed well visualized architecture with predominant nucleus. Liver sections of streptozotocin induced diabetic rats showed marked structural alterations in the liver 35 . The major alteration was periportal fatty infiltration, necrosis of hepatocytes 36 . This damage was reversed and regeneration of parenchyma cells by the leaf extract of Centratherum anthelminticum (300mg/BW) and Glibenclamide treatments (plate.1)

\section{Histology of pancreas 37}

Photomicrographs of pancreas showed normal acini and normal cellular population in the islets of langerhans in pancreas of control rats 38. Pancreas sections of streptozotocin induced diabetic rats showed extensive damage to the islets of langerhans and reduced dimensions of islets 39. Photomicrograph of Pancreatic Islets of Streptozotocin induced rat treated with Centratherum anthelminticum $(300 \mathrm{mg} / \mathrm{kg})$ and Glibenclamide $(1 \mathrm{mg} / \mathrm{kgbw})$ showing regeneration of Islets of Langerhans, blood vessels and acinus (plate.2).

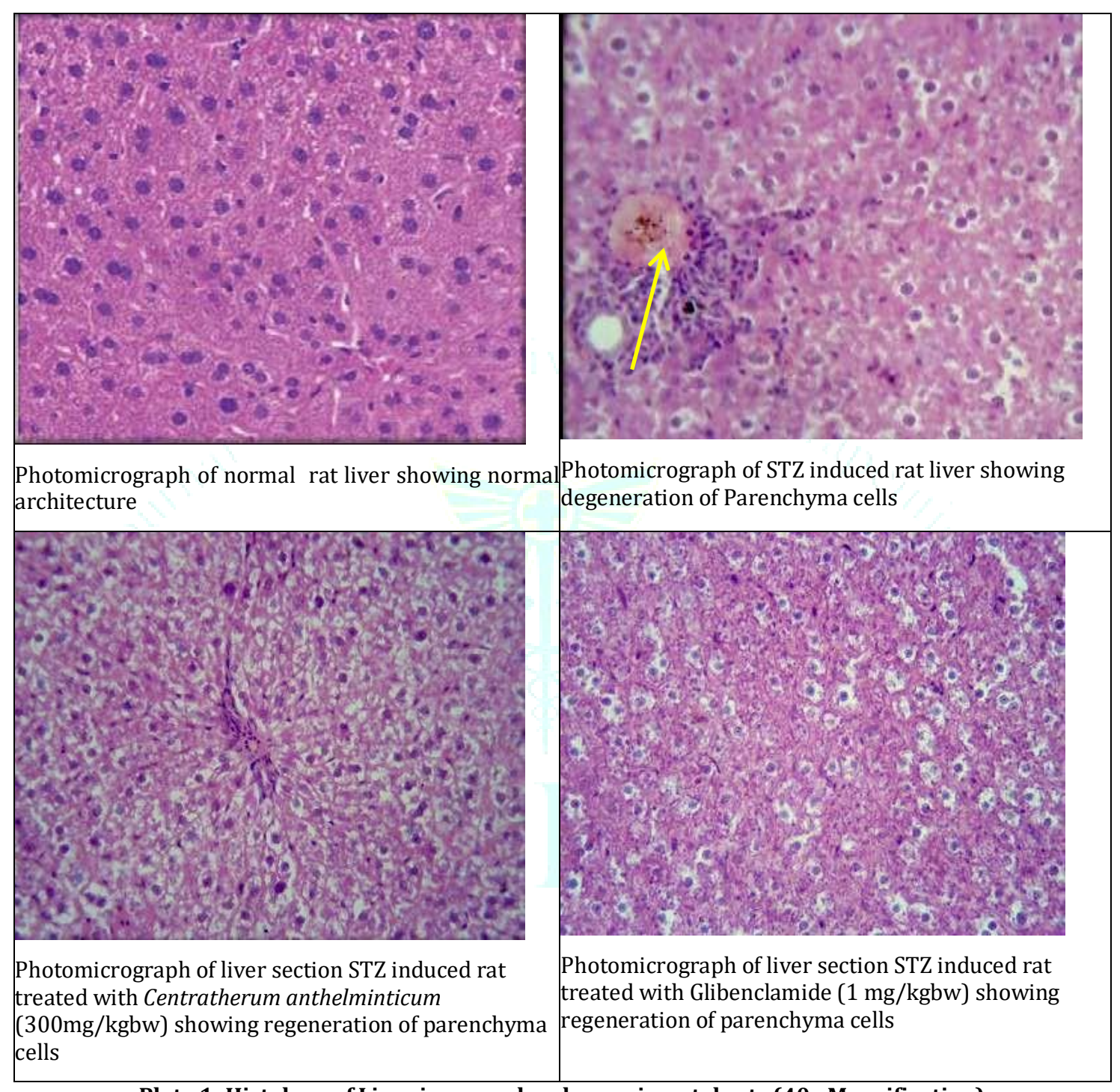

Plate.1: Histology of Liver in normal and experimental rats (40x Magnification) 

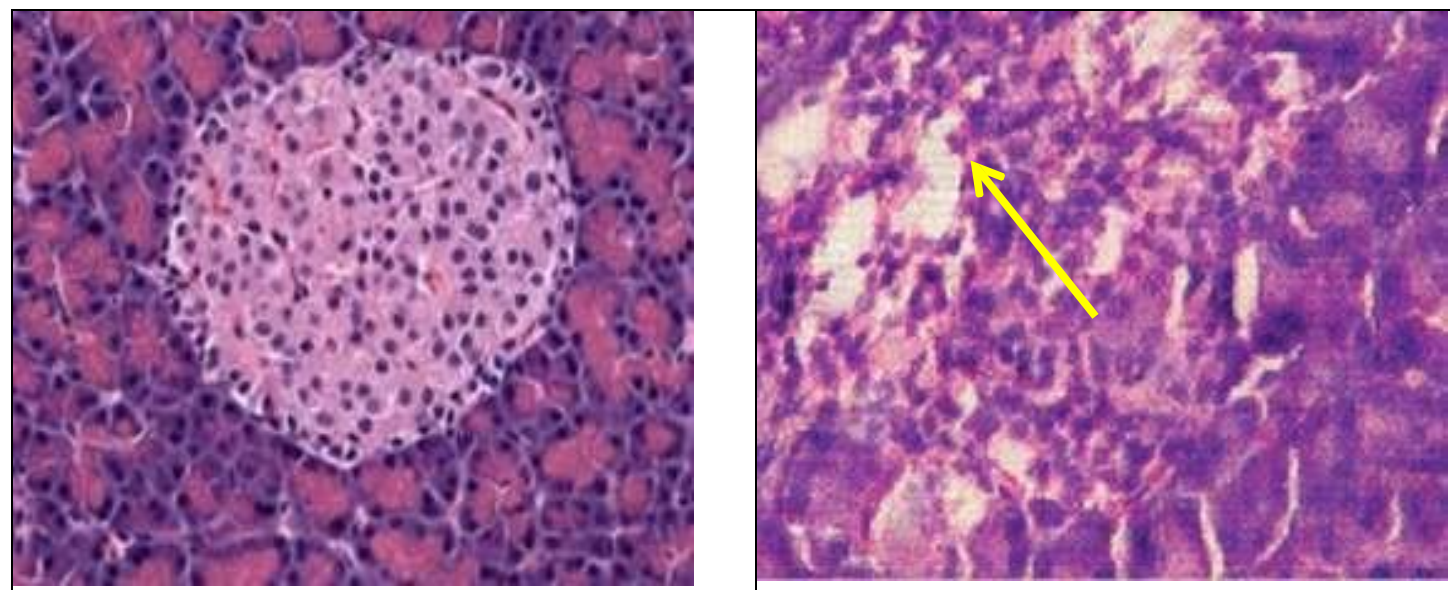

Photomicrograph of pancreatic islet of normal rat Photomicrograph of Pancreatic Islets of STZ induced showing normal islet of Langerhans, blood vessel andrat showing degeneration of islet Langerhans, blood Acinus

vessel and Acinus
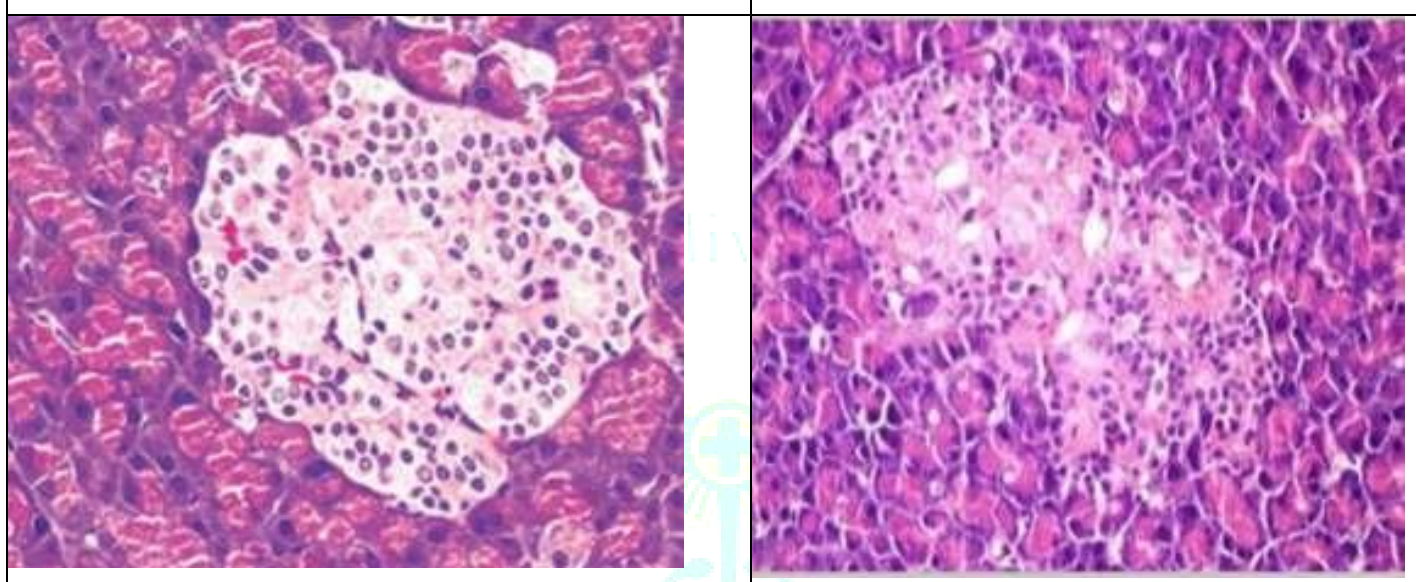

Photomicrograph of Pancreatic Islets of STZ induced Photomicrograph of Pancreatic Islets of STZ induced rat treated with Centratherum anthelminticum rat treated with Glibenclamide $(1 \mathrm{mg} / \mathrm{kgbw})$ showing (300mg/ kgbw) showing Regeneration of islet Regeneration of islet Langerhans, blood vessel and Langerhans, blood vessel and Acinus

Acinus

Plate.2: Histology of pancreas in normal and experimental rats (40x Magnification)

\section{SUMMARY}

Overall, the experimental studies suggest that Centratherum anthelminticum ethanolic seeds extract has potential antioxidant and antidiabetic activity ${ }^{40}$. This study is the first scientific report that provides convincing Phytochemical and ethno pharmacological evidence for the relevance of Centratherum anthelminticum, thus providing scientific validity to its traditional consumption by the local populace of south India. The antioxidant and antidiabetic activity of Centratherum anthelminticum ethanolic seeds might be present in bioactive compounds 41 .

Acknowledgement: The authors are thankful to L.T.R. Institute of Technology, Baghpat Road, Meerut, Uttar Pradesh 250002 for assistance towards this research work.

\section{Conflict of Interest:}

The authors declare no conflict of interest.

\section{REFERENCES}

1. Badarinath AV, Rao KM, Chetty CMS, Ramkanth V, A review on in-vitro antioxidant methods: comparisons, correlations and considerations. Int. J. PharmTech Res, 2010; 2, 1276-1285.

2. Baker H, Frank O, De Angeles, Feinglod S, Plasma $\alpha$-tocopherol in man at various times after ingesting free or acetylated tocopherol. Nutrition Reports International, 1980; 21, 531-534.

3. Banerjee S K, Bonde CG. Total phenolic content and antioxidant activity of extracts of Bridelia retusa Spring Bark: Impact of dielectric constant and geographical location. J Med Plants Res, 2011; 5, 817-822.

4. Blokhina O, Virolainen E, Fagersted KV.Antioxidants, oxidative damage and oxygen deprivation stress: a review. Annals Bot 2003; 91, 2, 179-94.

5. Chakravarthy BK, Gupta S, Gambhir SS, Grode KD, Pancreatic beta cell regeneration. A novel anti-diadetic mechanism of Pterocarpus marsupium Rob. Indian journal of pharmacology, 1980; 12, 123-127.

6. Chance B, Grenstein DS, Roughton RJ, The mechanism of catalase action 1- steady state analysis. Arch Biochem Biophy, 1952; 301-339.

7. Chaouki S, Houria M, Mohammed El Amine Dib., Meriem Z, Boufeldja T, Anti-diabetic activity of aqueous root extract of Anacyclus pyrethrum L. in streptozotocin-induced diabetic rats. Journal of Medicinal Plants Research, 2012; 6, 16, 3193-3198.

8. Dorman HJD, Peltoketo A, Hiltunen R, Tikkane MJ, Characterisation of the antioxidant properties of deodourisation aqueous extracts from selected Lamiaceae Herbs. Food Chem, 2003; 83, 255-256.

9. Dukes, Phytochemical and Ethnobotanical Databases Phytochemical and Ethnobotanical Databases, 2003; www.arsgov/cgi-bin/duke/.

10. Duh PD, Tu YY, Yen GC, Antioxidant activity of water extract of 
Harng Jyur. (Chyrsanthemum morifolium Ramat). LWT-Food Sci. Technol, 1999; 32, 269-277.

11. Duraipandiyan V, Al-Dhab NA, Irudayaraj SS, Christudas S, Hypolipidemic activity of friedelin isolated from Azima tetracantha in hyperlipidemic rats. Revista Brasileira de Farmacognosia, 2016; 26, 89-93.

12. Abate N, Chandalia $M$, The impact of ethnicity on type 2 diabetes. Journal of diabetes and its Complications, 2003; 17, 39-58.

13. Abdallah IZ, Evaluation of Hypoglycemic Activity of Opuntia dillenii Haw Fruit Juice in Streptozotocin-Induced diabetic rats. The Egyptian Journal of Hospital Medicine, 2008; 33, 544-558.

14. Abdul J, Hussain AZ, Water Quality Index of Uyyakondan Channel of River Cauvery at Tiruchirappalli. IJEP,2005; 25, 10, $941-942$.

15. Mannan A, Beauty AR, A Quick Review on Anti-diabetic Plants and Action of Phytochemicals. International Journal of Advanced Research, 2004;2, 5, 227-249.

16. Abdul Z, AO Salim, Assaf MH, Antidiabetic activity and toxicity of Zizyphus spina-christi leaves. J.Ethnopharmacol, 2005; 3, 101(13), 129-38.

17. Al-Sharmony L, Al-Khazraji SM, Twaji HA, Hypoglycemic effect of Artemisia herb alba II. Effect of a valuable extract on some blood parameters in diabetic animals. J Ethno Pharamacol, 1994; 43, 167-171.

18. Anandi C, Alaguraja D, Natarajan V, Ramanathan M, Subramaniam C S, Thulasiram, M. Bacteriology of diabetic foot lesions. Indian J Med Microbiology, 2004; 22,175-8.

19. Ananthan R, Latha M, Ramkumar KM, Pari L, Basker L, Narmatha Bai V. Antidiabetic effect of Gymnema montanum leaves: effect on lipid peroxidation induced oxidative stress in experimental diabetes. Nutrition, 2004; 6, 379 - 386.

20. Arathi G, Sachdanandam, Therapeutic effect of Semecarpus and Cardium Linn, nut milk extract on carbohydrate metabolizing and mitochondrial TCA cycle and respiratory chain enzymes in mammary carcinoma rats, J. Pharm and Pharmol,2003; 55, 1283-1290.

21. Arthika S, Shanthammal Y, Sheryl IN, Hepatoprotective Activity of the Ethanoilc Extract of Azima tetracantha against Paracetamol-Induced Hepatotoxicity in Wistar Albino Rats. Journal of Advances in Pharmacy and Healthcare Research, 2011;1, 2, 14-21.

22. Arumugam S, Gopal M, Gopalakrishnan S, Ravikanth $P$, Prakasam G, Anand M, Screening of antibacterial properties of Indian medicinal plants against multi drug resistant diabetic foot ulcer isolates. International Journal of Phytopharmacology, 2012; 3, 2, 139-146.

23. Atmani D, Chaher N, Berboucha M, Ayouni K, Lounis $H$, Boudaoud H, Debbache N, Atmani D. Antioxidant capacity and phenol content of selected Algerian medicinal plants. Food Chem, 2009; 112, 303-30.

24. Awoyinka OA, Balogun IO, Ogunnow AA. Phtochemical screening and in vitro bioactivity of Cnidoscolus aconitifolius (Euphorbiaceae). J. Med. Plant Res,2007; 1, 63-95.

25. Blytt HJ, Guscar TK, Butler LG, Antinutritional effects and ecological significance of dietary condensed tannins may not be due to binding and inhibiting digestive enzymes. Journal of Chemical Ecology, 1988; 14, 1455-1465.

26. Bolaffi JL, Nagamatsu S, Harris J, Grodsky GM, Protection by thymidine, an inhibitor of polyadenosine diphosphate ribosylation, of streptozotocin inhibition of insulin secretion. Endocrinology, 1987; 120, 2117-2122.

27. Bonting SL, Bilter EE, Membrane and ion transport, London Wiley Interscience, 1970;257.

28. Bopana KN, Kannan J, Sushma gangil, Blaraman R, Rathod SP, Antidiabetic and anti hyperlipedemic effect of Neem, Lipedemic effect of Neem seed kernel powder on alloxon diabetic rabbits. Ind. J. Pharmacology, 1977; 29, 162-167.

29. Bora KS, Sharma A. In-Vitro Antioxidant and Free Radical Scavenging Potential of Medicago sativa Linn. J. Pharma. Res, 2011; 3, 1206-1210.

30. Brahmachari G. Six Bio-flavonoids with promising antidiabetic potentials: a critical survey, in Opportunity, Challenge and Scope of Natural Products in Medicinal Chemistry, 2011; 187-212.

31. Brandstrup N, Kirk JE, Brunic, The hexokinase method and phosphoglucoisomerase activities and aortic pulmonary artery in individuals of various ages, J Gerontol, 1957;12, 166.

32. Brownlee M, Cerami A, Advanced glycosylation end products in tissue and the biochemical basis of diabetic complications. $N$ Engl J Med, 1981; 318, 1315-1321.

33. Bruce A, Freeman D, James C, Biology of disease-free radicals and tissue injury. Lab Invest, 1982; 47, 412-26.

34. Caraway WT, Determination of uric acid in serum by carbonate method. Am J Clin Path, 1955; 25, 840-845.

35. Caroll NV, Longly RW, Roe JH, The determination of glycogen in liver and muscle by use of anthrone reagent, J. Biol Chem., 1956;220, 58.

36. CDER. (1994). Reviewer Guidance: Validation of Chromatographic Methods. FDA. CDER. (2004). Guidance for Industry Analytical Procedures and Methods Validation. FDA.

37. Chakrabarti R, Rajagopalan R, Diabetes and insulin resistance associated disorders. disease and the therapy. Current Science, 2002; 83, 12, 1533-8.

38. Chelladurai V, Millikizhangu- an unique folk medicinal plant from the adivasis (tribals) of point calimare, Tamilnadu. Bull Med Ethno Bot Res, 1983; 4, 4148-153.

39. Chen KK, Robert CA, McCowen MC, Harris PN, Pharmacological action of hypoglycin A \& B. The J Phar Exp Pharmacol, 1957; 121, 272-285.

40. Cheng AY, Fantus IG, Oral antihyperglycemic therapy for type 2 diabetes Mellitus Can. Med. Assoc. J, 2005;17, 2, 213-26.

41. Pulok KM, Kuntal M, Kakali M, Peter JH, Leads from Indian medicinal plants with hypoglycemic potentials. Journal of ethnopharmacology, 2007; 106, 1-28. 